\title{
Analysis of four achaete-scute homologs in Bombyx mori reveals new viewpoints of the evolution and functions of this gene family Qingxiang Zhou ${ }^{1}$, Tianyi Zhang ${ }^{2}$, Weihua $\mathrm{Xu}^{2}$, Linlin $\mathrm{Yu}^{1}$, Yongzhu $\mathrm{Yi}^{1}$ and Zhifang Zhang*1
}

\author{
Address: ${ }^{1}$ The Biotechnology Research Institute, National Engineering of crop germplasm and genetic improvement, Chinese Academy of \\ Agricultural Sciences, Beijing, 100081, China and 2State Key Laboratory for Biocontrol and Institute of Entomology, School of Life Sciences, SUN \\ YAT-SEN University, Guangzhou 510275, China \\ Email: Qingxiang Zhou - Qingxiang_Zhou@meei.harvard.edu; Tianyi Zhang - Tianyi_Zhang@meei.harvard.edu; \\ Weihua Xu - Xuweihua@mail.sysu.edu.cn; Linlin Yu - Linlinyu1983@126.com; Yongzhu Yi - Yongzhuyi62@yahoo.cn; \\ Zhifang Zhang* - Zhifangzhang@yahoo.com \\ * Corresponding author
}

This article is available from: http://www.biomedcentral.com/l47I-2/56/9/24

(c) 2008 Zhou et al; licensee BioMed Central Ltd.

This is an Open Access article distributed under the terms of the Creative Commons Attribution License (http://creativecommons.org/licenses/by/2.0), which permits unrestricted use, distribution, and reproduction in any medium, provided the original work is properly cited.

\begin{abstract}
Background: achaete-scute complexe (AS-C) has been widely studied at genetic, developmental and evolutional levels. Genes of this family encode proteins containing a highly conserved bHLH domain, which take part in the regulation of the development of central nervous system and peripheral nervous system. Many AS-C homologs have been isolated from various vertebrates and invertebrates. Also, AS-C genes are duplicated during the evolution of Diptera. Functions besides neural development controlling have also been found in Drosophila AS-C genes.
\end{abstract}

Results: We cloned four achaete-scute homologs (ASH) from the lepidopteran model organism Bombyx mori, including three proneural genes and one neural precursor gene. Proteins encoded by them contained the characteristic bHLH domain and the three proneural ones were also found to have the $\mathrm{C}$-terminal conserved motif. These genes regulated promoter activity through the Class A E-boxes in vitro. Though both Bm-ASH and Drosophila AS-C have four members, they are not in one by one corresponding relationships. Results of RT-PCR and real-time PCR showed that $B m$ $A S H$ genes were expressed in different larval tissues, and had well-regulated expressional profiles during the development of embryo and wing/wing disc.

Conclusion: There are four achaete-scute homologs in Bombyx mori, the second insect having four $A S-C$ genes so far, and these genes have multiple functions in silkworm life cycle. AS-C gene duplication in insects occurs after or parallel to, but not before the taxonomic order formation during evolution.

\section{Background}

Transcriptional factors of the bHLH (basic helix-loophelix) family play important roles in the development of metazoan, taking part in the regulation of neurogenesis, myogenesis, haemopoiesis and so on [1-5]. The achaete- scute complex (AS-C), a group of four bHLH genes, has been found to be involved in the determination of Drosophila neural precursors [6-9]. 
AS-C proteins interact with another bHLH protein Daughterless (Da) to form a dimer, and bind Class A E-boxes CAGG/CTG [10]. AS-C/Da heterodimers' binding sites were found in the upstream regions of hunchback $(h b)$ [10] and phyllopod (phyl) [11]. In Drosophila, they were also found in the upstream region of ac itself, and required for auto- and cross-regulation by $a c$ and $s c$ [12].

The main functions of $A S-C$ genes are regulating the formation and patterning of precursors of central nervous system (CNS) and peripheral nervous system (PNS). During neural development, $A S-C$ genes are expressed in one or more cells within the proneural clusters, which are committed to the neural precursor fate, and the remaining cells in the cluster differentiate to be epidermal cells or are eliminated by apoptosis $[8,13,14]$. Tribolium castaneum ASH (Tc-ASH) and Hydra vulgaris cnidarian ASH (Cn-ASH) show similar functions during the formation of sensory organs in the transgenic Drosophila $[15,16]$. Also, it was found that Cn-ASH protein formed heterodimers with Drosophila Da (Dm-Da) protein in vitro, and these dimers specially bound to the consensus E-boxes [15]. Besides regulation of neurogenesis, AS-C genes have other functions. ac takes part in the development of Malpighian tubule by expressing in the tip cell and regulating the sequential fates of the organ [17]. sc regulates sex determination by its different expression dosage between females and males, but neither $a c$ nor $l$ 'sc can substitute for $s c$ in this function [18-20]. l'sc expression is necessary for muscle founder cells segregating from the somatic mesoderm. Loss of expression of l'sc leads to a loss, whereas over expression causes a duplication of muscles and founder cells [21].

According to the sequence and functional analysis in different species, AS-C genes are conserved during evolution. The four genes of Drosophila AS-C are achaete (ac), scute $(s c)$, lethal of scute (l'sc) and asense (ase). The former three are defined as proneural genes and the last one as neural precursor gene, basing on their expression patterns and functions in proneural clusters. AS-C homologs have been isolated from various invertebrates and vertebrates $[15,16,22-34]$. They all have a conserved bHLH domain and some of them also have a conserved C-terminal motif. Gene duplication events caused a dramatic increase of $A S$ $C$ gene number during Arthropoda evolution [16,30]. Within Insecta, AS-C homologs have been studied in Diptera (flies and mosquitoes), Hymenoptera (bees), Coleoptera (the red flour beetle) and Lepidoptera (the butterfly $P$. coenia). Each of the insects has one ase-like gene. Most of them have only one proneural gene, while the medfly Ceratitis capitata has two, and the fruit fly has three. The four genes in Drosophila were believed to have arisen from a single ancestral gene by three independent duplication events [16,30]. AS-C homologs in the insects studied are closely linked in the chromosome, for example, the four $A S-C$ genes comprising about $100 \mathrm{~Kb}$ in Drosophila, and the two residing about $22 \mathrm{~Kb}$ apart in Anopheles, about 55 $\mathrm{Kb}$ apart in Tribolium, and about $40 \mathrm{~Kb}$ apart in Apis $[16,34]$.

The silkworm, Bombyx mori, is a model organism of Lepidoptera. With the completion of silkworm genomic sequencing project [35], Bombyx mori is emerging as an important model lepidopteran. Only one AS-C homolog had been isolated from lepidopteran in previous studies [26]. In the present study, we found there were four $A S-C$ homologs in silkworm, three proneural genes and an aselike one. We detected the transcriptional activity of the genes by transient expression in Bm-N cells. Expression profiles of the genes in different tissues and expression changes during the development course of silkworm embryo and wing disc/wing were also studied.

\section{Results \\ Isolation and identification of achaete-scute homologs in Bombyx mori}

It is well known that each achaete-scute homolog has a highly conserved bHLH domain which distinguishes them from other bHLH proteins. Using the amino acid sequence of Drosophila Ac (Genbank: AAF45498) to blast the silkworm EST database (see Materials and Methods section), we obtained an EST sequence (GenBank: CK537057) encoding a conserved AS-C bHLH domain. Primers were designed based on the EST sequence, and RACE assay was carried out using the midgut total RNA of $3 \mathrm{~d} 5^{\text {th }}$ instar larva as the template. After sequencing and assembling, we gained a cDNA of 1,332 bp and named it Bm-ASH1 (Genbank: DQ350889). Bm-ASH1 gene contains a 582 bp ORF region (including the stop codon) and encodes a 193 aa protein.

Then we screened the Bombyx mori genome database using the 193 aa Bm-ASH1 protein sequence, and found genes with conserved AS-C bHLH region in four more contigs (Genbank: $\quad$ AADK01030307, AADK01036667, $\underline{\mathrm{AADK} 01011379}$ and BAAB01105243), besides the two (Genbank: $\underline{\text { AADK01005140 }}$ and BAAB01089921) corresponding to Bm-ASH1. BAAB01105243 is part of AADK01011379. Each of them contained a deduced ORF region, and then we cloned the ORF regions by RT-PCR methods and they were sequenced. Primers for 3'-RACE were designed basing on the sequences of the ORF regions, and 3'-RACE assay was processed using the total RNA from $1 \mathrm{~d}$ pupal wing as the template. The segments gained by 3'-RACE were sequenced and assembled with each corresponding ORF sequence. The final cDNA sequences were 1,449 bp, $990 \mathrm{bp}$ and 1,695 bp long, and were named Bm-ASH2 (Genbank: EF620927), Bm-ASH3 (Genbank: EF620928) and Bm-ase (Genbank: EF620929) 
respectively. Bm-ASH2 gene contained a 720 bp OFR region (including the stop codon) and encoded a 239 aa protein, $B m-A S H 3$ gene contained a 726 bp OFR region (including the stop codon) and encoded a 241 aa protein, and Bm-ase gene contained a 1,215 bp OFR region (including the stop codon) and encoded a 404 aa protein.

Alignment results with Drosophila AS-C proteins showed that all four proteins encoded by $B m-A S H$ genes contained the $A S-C$ characteristic one basic and two helix domains flanking a non-conserved loop domain (Fig. 1). Bm-ASH1, Bm-ASH2 and Bm-ASH3 also had the C-terminal 16-17 aa conserved motif, but Bm-Ase did not. There was a highly conserved short motif (SPxxS, x means uncertain acid amino) around the region of PEST domain [3638 ]. In the bHLH region, Bm-ASH1 shares $74.6 \%, \mathrm{Bm}-$ ASH2 shares $72.1 \%$ and Bm-ASH3 shares $72.1 \%$ amino acid identity with Dm-L'sc, and Bm-Ase shares $74.3 \%$ with Dm-Ase (Table 1). The data above indicate that $\mathrm{Bm}$ $A S H 1, B m-A S H 2$ and $B m-A S H 3$ are proneural genes and $B m$-ase an asense homolog.

We compared the sequences of ASH proteins from silkworm and some other insects, and found that either at whole amino acids level or within the bHLH region, BmASH1 had a higher identity with non-lepidopteran insects'

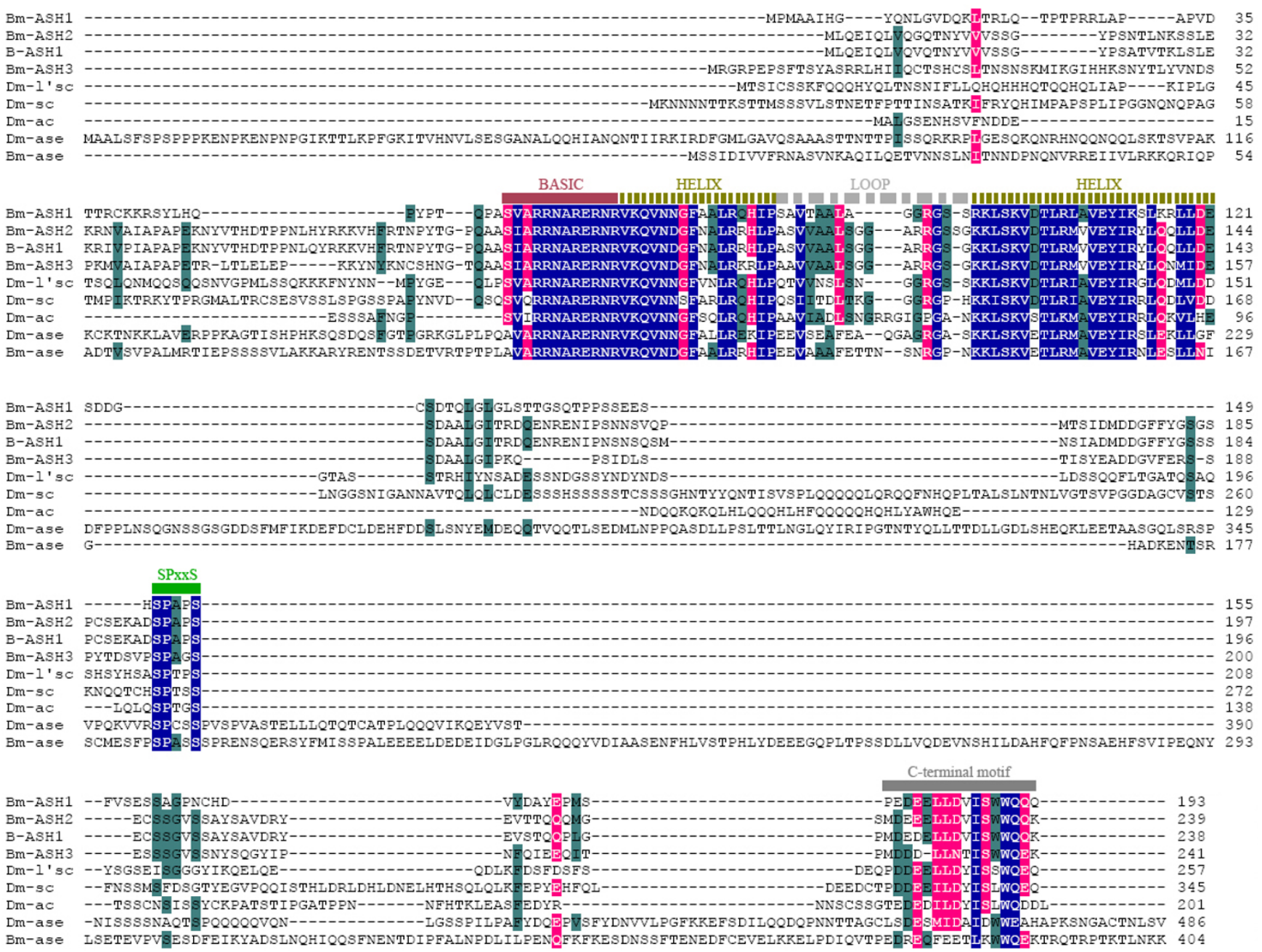

Figure I

Alignment of the amino acid sequences of proteins encoding by Bm-ASH, B-ASHI and Dm AS-C genes. All of the proteins contain the AS-C characteristic one basic and two helix domains flanking a non-conserved loop domain, and a conserved C-terminal 16-I7 aa motif also exists in each of the proneural genes but neither of the asense genes. Moreover, a conserved short motif SPxxS is also found in all of the investigated proteins. Amino acids that are similar in $100 \%$ of aligned sequences are shaded blue, in more than $80 \%$ but less than $100 \%$ with pink, and in more than $60 \%$ but less than $80 \%$ with darkgreen. 
Table I: Homology comparison of proteins encoded by the BmASH genes with other insect ASH proteins.

\begin{tabular}{lcccr}
\hline ASH name & \multicolumn{5}{c}{ Percent Identity (\%) } \\
\cline { 2 - 5 } & Bm-ASHI & Bm-ASH2 & Bm-ASH3 & Bm-Ase \\
\hline Bm-ASHI & $I$ & & & \\
Bm-ASH2 & $71.6(44.6)$ & $I$ & & \\
Bm-ASH3 & $70.1(36.8)$ & $91.3(49.8)$ & $l$ & \\
B-ASHI & $73.1(38.9)$ & $100.0(90.3)$ & $91.3(47.9)$ & $66.7(26.5)$ \\
Ag-ASH & $79.1(47.7)$ & $70.6(34.3)$ & $70.6(30.7)$ & $67.6(19.7)$ \\
Am-ASH & $77.6(50.8)$ & $67.1(32.2)$ & $63.8(26.1)$ & $68.6(25.8)$ \\
Dm-Ac & $68.7(31.6)$ & $65.7(28.9)$ & $65.2(30.3)$ & $60.0(28.4)$ \\
Dm-Sc & $68.7(42.0)$ & $62.3(27.2)$ & $58.0(27.4)$ & $59.4(21.2)$ \\
Dm-L'sc & $74.6(40.9)$ & $72.1(31.0)$ & $72.1(36.9)$ & $61.8(27.2)$ \\
Tc-ASH & $76.1(46.6)$ & $62.9(34.3)$ & $63.8(26.1)$ & $67.1(28.1)$ \\
Bm-Ase & $67.2(31.1)$ & $62.9(30.1)$ & $60.9(27.0)$ & 1 \\
Ag-Ase & $68.7(30.1)$ & $54.3(20.9)$ & $56.5(21.6)$ & $71.4(22.0)$ \\
Am-Ase & $73.1(38.9)$ & $68.8(26.8)$ & $62.5(23.7)$ & $71.9(24.9)$ \\
Dm-Ase & $70.1(37.8)$ & $57.1(23.0)$ & $60.9(24.5)$ & $74.3(24.0)$ \\
Tc-Ase & $70.1(36.8)$ & $63.2(25.1)$ & $58.8(26.1)$ & $77.9(33.5)$
\end{tabular}

The number in the bracket is the identity percent between two whole protein sequences, and the number before the bracket is the identity percent within the bHLH regions.

ASH proteins than the other two Bombyx proneural proteins, Bm-ASH2 and Bm-ASH3 (Table 1). Among the silkworm ASH proteins, Bm-ASH2 and Bm-ASH3 are most identical, showing $91.3 \%$ identity within the bHLH region. It is surprising that $\mathrm{Bm}-\mathrm{ASH} 2$ and butterfly Achaete-scute homolog1 (B-ASH1) [26] are the same within the bHLH region and share $90.3 \%$ identity at the whole amino acid level. Bm-Ase shares more than $70 \%$ identities with all of the other insect Asense proteins within the bHLH region. In phylogenetic analysis, proneural proteins and Asense proteins were grouped into two separate clades (Fig. 2). In the proneural clade, Bm-ASH1, Dm-L'sc, $\mathrm{Ag}-\mathrm{ASH}, \mathrm{Am}-\mathrm{ASH}$, and Tc-ASH were grouped into one sub-clade, paralleling the other two sub-clades, one comprised of Dm-Ac and Dm-Sc and the other comprised of Bm-ASH1, Bm-ASH2 and B-ASH1.

\section{The Bombyx ASH genes could not be assembled into a complex based on current data}

cDNA sequence of each Bombyx ASH gene was used to blast the silkworm knowledgebase [39], and four separate scaffolds were screened out. The total length of the scaffolds is about $122 \mathrm{~Kb}$ (but we could not assemble them into one complex with the present data). Analysis results showed that there was an intron outside of the ORF region in $B m-A S H 1$ and $B m-A S H 2$, however there was no intron in either Bm-ASH3 or Bm-ase (Fig. 3).

\section{Bm-ASH genes regulating promoter activity via E-box in $\mathrm{Bm}-\mathrm{N}$ cells}

$A S-C$ genes have self-regulating functions by E-boxes in their promoter regions [12]. We cloned a 1,178 bp DNA fragment upstream of the ORF region of the $\mathrm{Bm}-\mathrm{ASH} 2$ gene. At positions 188-194 bp and 791-797 bp upstream of ATG codon, there are two Class A E-boxes (CAGG/ CTG). The promoter segments were cloned into pGL3Basic vector with a luciferase reporter gene, and $\mathrm{Bm}-\mathrm{ASH}$ and $d a$ genes was cloned into the modified transient expression vector pBacPAK8-ie1-hr3 [40]. Recombined plasmids were co-transfected into Bm-N cells by different assorted ways. We found that the promoter had no activity without the co-transfection of $B m-A S H$ or $d a$ genes' transient expression vectors (Fig. 4). The promoter had a significantly higher activity by co-transfection with $\mathrm{Bm}$ - $\mathrm{ASH} 1$ and the $d a$ genes' transient expression vectors than by other co-transfections. Besides, the promoter activity was weaker when it was only co-transfected into cells with $\mathrm{Bm}$ ASH genes than when also with $d a$ (ex., promoter activity of ASH2P+ASH1 was weaker than that of ASH2P+ASH1+ da, Fig. 4).

In order to study whether the bHLH transcriptional factors regulate the promoter by the E-box region, we changed one or both of the deduced E-boxes to "aAGG/ CcG" by site-directed mutation (Fig. 5A). Then the mutated promoters were cloned into pGL3-Basic vector as described above, and co-transfected Bm-N cells with each $B m-A S H$ and $d a$ genes' transient expression vectors, respectively. The results showed that E-box mutation significantly reduced the activity of the promoter when cotransfected with silkworm proneural genes (Fig. 5B, C, D; $p<0.01)$. However, the activation of $B m$-ase did not seem to be related with either of the two deduced E-boxes (Fig. $5 \mathrm{E} ; p>0.05)$. These data suggest that proteins encoded by $B m-A S H$ genes have similar functions to the AS-C transcriptional factors in Drosophila, and they synergize with Da protein.

\section{Expression distribution of Bombyx ASH genes in larval tissues}

To understand the potential in vivo regulations of $A S H$ genes, we detected the expression status of Bombyx ASH genes in different tissues of the 5th instar larvae on the 3rd and the 8th days (just after spinning) (Fig. 6). The data showed that Bm-ASH1 and Bm-ASH2 were expressed in organs derived from all the three cellular derms: ectoderm, mesoderm and endoderm; whereas $\mathrm{Bm}-\mathrm{ASH} 3$ and $\mathrm{Bm}$-ase were only expressed in tissues derived from ectoderm and mesoderm. Bm-ASH1 was expressed in all organs except silk glands (S-G) and hemocytes (He), and at a low level in $5 \mathrm{~d}$ and had no expression in $8 \mathrm{~d}$ fat body (FB). Bm-ASH2 was widely expressed in all the investigated samples. The expression of Bm-ASH3 and Bm-ase 


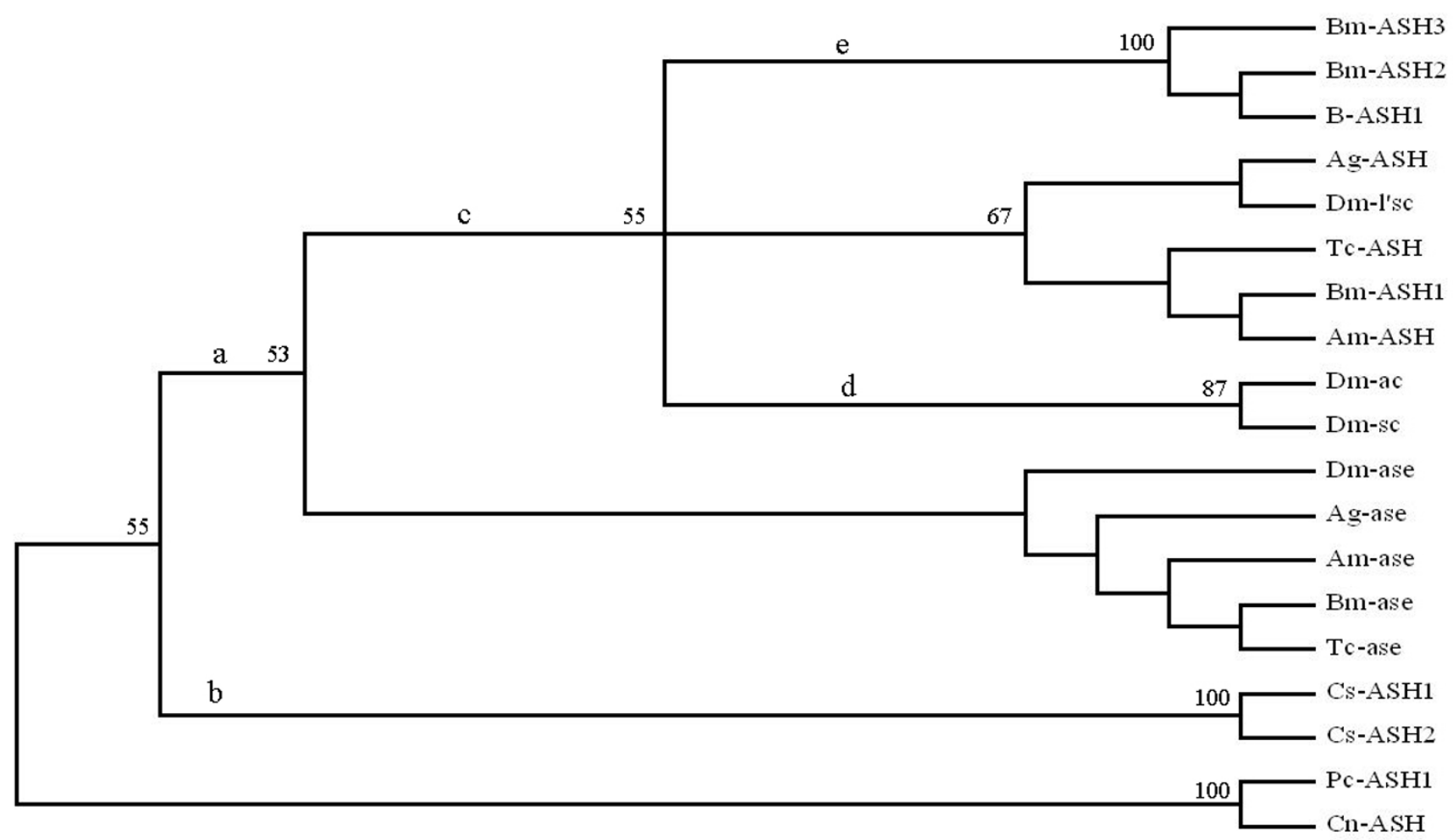

Figure 2

Phylogenetic status of silkworm ASH proteins in insect. The support values are given at each node (I00 replications). Branch lengths are not drawn to scale. Letters upside of the branch lines show the duplication events as clarified by Wheeler et al. [16] (see discussion for detailed description). It is obvious that all of the Asense proteins are grouped to one clade and the proneural genes are grouped to another within the insect group. Bm-ASH2 and Bm-ASH3 are grouped to a sub-clade parallel the one which Bm-ASHI is sorted in. Ag-ASH, Anopheles gambiae Achaete-Scute homolog (Genbank: AAK9746I); AmASH,Apis mellifera Achaete-Scute homolog (Genbank: XP 393665); B-ASHI, Butterfly (Genbank: Precis coenia) Achaete-Scute homolog I (Genbank: AAC247I4); Bm-ASHI, Bombyx mori Achaete-Scute homolog I (Genbank: NP 0010374I6); Bm-ASH2, Bombyx mori Achaete-Scute homolog 2 (Genbank: EF620927); Bm-ASH3, Bombyx mori Achaete-Scute homolog 3 (Genbank: EF620928); Cn-ASH, Hydra vulgaris cnidarian Achaete-Scute homolog (Genbank: U36275); Cs-ASHI, Cupiennius salei AchaeteScute homolog I (Genbank: CAC275I6); Cs-ASH2, Cupiennius salei Achaete-Scute homolog 2 (Genbank: CAC275I7); Dm-ac, Drosophila melanogaster Achaete (Genbank: AAF45498); Dm-sc, Drosophila melanogaster Scute (Genbank: AAF45499); Dm-l'sc, Drosophila melanogaster Lethal of scute (Genbank: AAF45500); Pc-ASHI, Podocoryne carnea Achaete-Scute homolog I (Genbank: AAN85I I0); Tc-ASH, Tribolium castaneum Achaete-Scute homolog (Genbank: AAQ23386); Ag-ase, Anopheles gambiae Asense (Genbank: AAABO 1008963); Am-ase, Apis mellifera Asense (Genbank: XP 393664); Bm-ase, Bombyx mori Asense (Genbank: EF620929); Dm-ase, Drosophila melanogaster Asense (Genbank: AAF45502); Tc-ase, Tribolium castaneum Asense (Genbank: AAQ23387).

were more tissue specific, and the level of Bm-ase was relatively lower. $B m-A S H 1$ and $B m-A S H 2$ had high expression levels in gonads (G), while $\mathrm{Bm}-\mathrm{ASH} 2$ and $\mathrm{Bm}-\mathrm{ASH} 3$ had high expression levels in tracheal clusters (Tc). All of the data suggested that the four $\mathrm{Bm}$-ASH genes might play various roles in the development of silkworm larva. We should note that all three proneural genes expressed highly in WD, and Bm-ase had a relatively higher expression level in $8 \mathrm{~d}$ WD. These implied that $B m$-ASH genes might be important for the development of the wing disc.

\section{Developmental changes of Bombyx ASH genes in the embryo and in the pupal wing}

Functional genes play their roles by expression in special tissues and at special time. We detected the expression level of Bombyx ASH genes in the embryo and pupal wing in order to study the function of these genes during silkworm development. Total RNA was extracted from $1 \mathrm{~d}$ to $9 \mathrm{~d}$ embryos or from wings/wing discs (from spinning to the adult phase), and used for reverse transcription. cDNA synthesized from about $10 \mathrm{ng}$ total RNA was taken as the template for each PCR reaction. We calculated the gene 

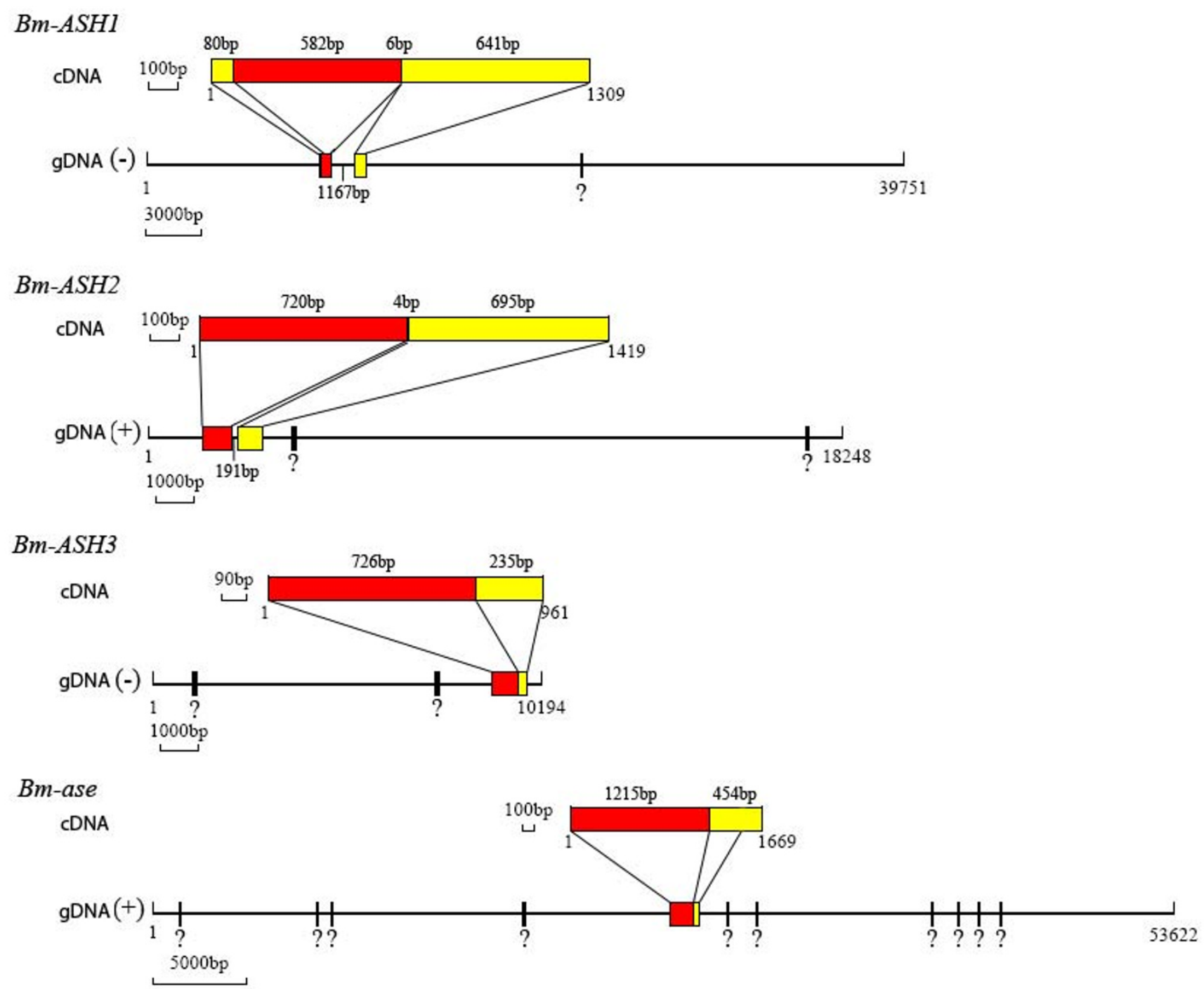

\section{Figure 3}

Genomic structure of Bm-ASH genes. The red region stands for the ORF, and the yellow region stands for non-coding regions; gDNA stands for genomic DNA; (+) and (-) show the published genomic sequences [39] being forward or reverse compared with the cDNAs. "?" shows the region unsequenced. The 6 bp in Bm-ASHI indicates that there is a 6 bp uncoding region in the first exon of the gene just following the coding region, so is the $4 \mathrm{bp}$ in $\mathrm{Bm}-\mathrm{ASH} 2$. Genomic sequences are all from SilkDB [39]. The name of the genomic DNA fragment in Bm-ASHI is Scaffold002070, in Bm-ASH2 is Scaffold0079I0, in Bm-ASH3 is Scaffold0I 3050, and in Bm-ase is Scaffold000880, respectively.

copy number corresponding to $10^{3} \mathrm{Bm}$-actin $\mathrm{A} 3$ copies at each developmental point in the embryo and $10^{6}$ in the wing/wing disc. The results showed that during the embryo development, both $\mathrm{Bm}$-ASH2 and $\mathrm{Bm}$-ase had two expression peaks, one being both on $3 \mathrm{~d}$, and the other being on $5 \mathrm{~d}$ for $\mathrm{Bm}$-ASH2 and on $6 \mathrm{~d}$ for Bm-ase (Fig. 7). However, there was only one peak for each of the other two Bm-ASH genes, Bm-ASH1 on $5 \mathrm{~d}$ and $B m$-ASH3 on 4 d. Although the expression levels of $B m-A S H 3$ showed a peak from $3 \mathrm{~d}$ to $5 \mathrm{~d}$, its expression level was always lower than the other three genes.

During the spinning (wandering) and pupal ages, the silkworm wing disc/wing form changes obviously by extension, turning and scale foundation. The results of quantitative RT-PCR showed that all four genes had relatively high expression levels from $0 \mathrm{~d}$ to $3 \mathrm{~d}$ pupae (Fig. 8). The result of $B m-A S H 1$ was similar to our previous results [41]. Bm-ASH1, Bm-ASH2 and Bm-ASH3 all reached their 


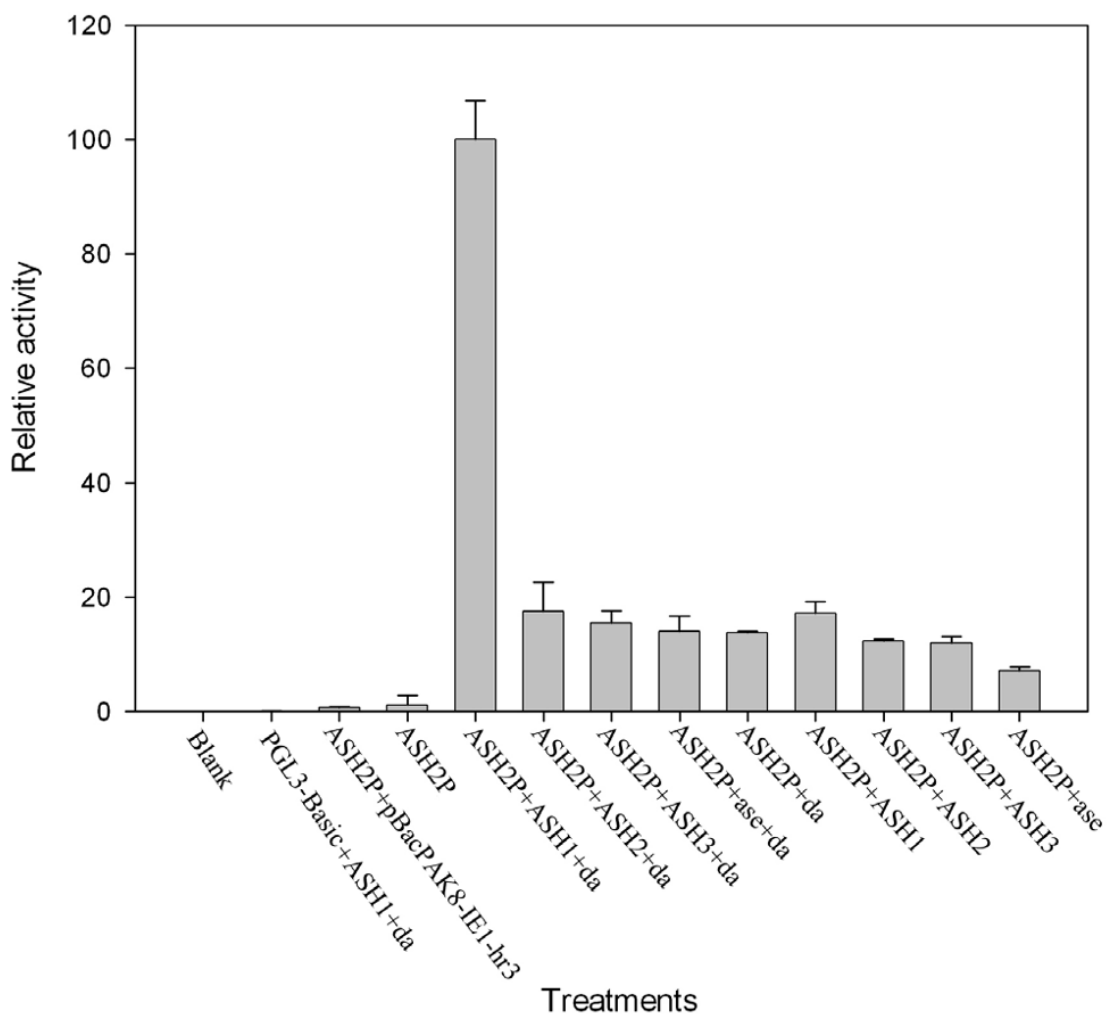

\section{Figure 4}

Activity analysis of ASH2P promoter by co-transfected with Bm-ASH genes. In the figure, ASH2P stands for the recombinanted plasmid pGL3-Basic-ASH2P; ASHI, ASH2, ASH3, ase and da respectively stands for the modified transient expression vector pBacPAK8-iel-hr3 containing Bm-ASHI, Bm-ASH2, Bm-ASH3, Bm-ase and Dm-da (daughterless) ORFs as transcriptional factor genes. At least three independent repeats were carried out for each treatment.

peak values on P-1 d, whereas Bm-ase peaked one day later. Flanking these days, expression levels of the genes were significantly lower. During the spinning period, expressions of all four genes were at low levels, with $\mathrm{Bm}$ ase being undetectable. It was notable that the expression levels of the three proneural genes decreased from S-0d to $\mathrm{S}-3 \mathrm{~d}$. Bm-ASH3 and Bm-ase were not express anymore after P-3d pupa, while both Bm-ASH1 and Bm-ASH2 had a low but noticeable peak in $5 \mathrm{~d}$ pupa.

\section{Discussion}

Our results showed that there were four $A S-C$ homologs in Bombyx mori: Bm-ASH1, Bm-ASH2, Bm-ASH3 and Bm-ase. The first three were proneural genes, and the last one was a neural precursor gene. The proneural genes enhanced the activity of the $\mathrm{Bm}$-ASH2 promoter by binding its Eboxes in Bm-N cells, which was one of the AS-C homolog characteristics (Figs. 4 \&5). The four genes had various expression profiles in silkworm larval tissues (Fig. 6), and further studies showed that they have important roles during the development of the embryo and the wing (Fig. 7 \&).

\section{AS-C genes duplication in insects occurs after or parallel but not before the taxonomic order formation during evolution}

Homologs of AS-C genes exist in various animals from low-grade coelenterate to high-grade mammals, including human being [30]. It has been proposed that $A S-C$ gene has several independent duplication events in Arthropoda, resulting in the plasticity of the gene number. In this model, $\mathrm{Cn}-\mathrm{ASH}$, the AS-C homolog in Hydra is supposed as the ancestral one. Parallel but independent duplication events occurred in insects and chelicerates (Fig. 2,a \&2b). Within the Diptera two more duplication events happened during evolution. So the present most derived dipteran, Drosophila melanogaster, has the four $A S-C$ genes achaete, scute, lethal of scute and asense $[16,30]$; while lower derived dipteran, such mosquito, has only two [31].

We found that there were four AS-C homologs in the silkworm, Bombyx mori, a model lepidopteran. Also, Bombyx is the only insect besides Drosophila found with four AS-C genes so far. Among the three proneural $A S-C$ genes in Drosophila, l'sc is the most original one, which is more 

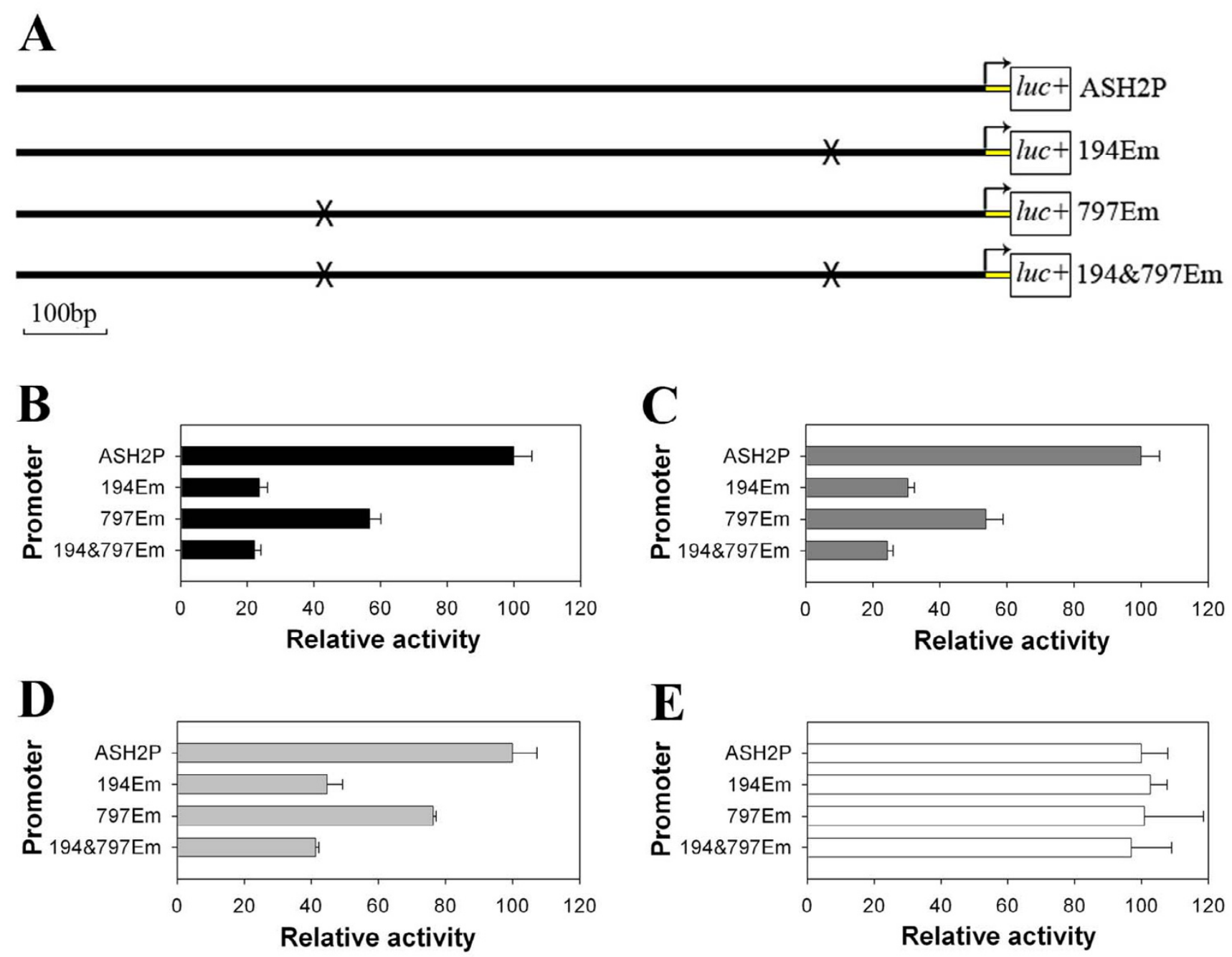

Figure 5

Bm-ASH genes enhance ASH2P Promoter activity via E-boxes. ASH2P, the promoter segment of $B m-A S H 2 ; 194 E m$, ASH2P mutated in the E-box 188-194 bp upstream from the start codon; 797Em, ASH2P mutated in the E-box 79I-797 bp upstream from the start codon; 1948797Em, ASH2P mutated in both of the E-boxes. Forks show the mutated E-box site (A). $B, C, D$ and $E$ are the results co-transfected of promoters and da with ASHI, ASH2, ASH3 and ase, respectively. E-boxes mutation significantly reduced the promoter activity in B, C and D $(p<0.0 \mathrm{I})$, but had no effect in $E(p>0.05)$.

identical to the proneural genes in other insects than $a c$ and sc (Table 2). Like l'sc, Bm-ASH1 is more identical to non-lepidopteran insect proneural genes than other silkworm achaete-scute homologs (Table 2). What's more, l'sc and $B m-A S H 1$, and other sole proneural genes from other insects were sorted into one clade in the phylogenetic tree (Fig. 2). The data imply that Bm-ASH1 is the most original one in Bombyx. But homogeneous and phylogenetic analysis could not match each Bombyx proneural gene to those of Drosophila one by one, and phylogenetic result sorted $\mathrm{ac} / \mathrm{sc}$ and $\mathrm{Bm}$-ASH2/Bm-ASH3 into two independent branches. So we suggest that the generations of $a c / s c$ from $l$ 'sc and Bm-ASH2/Bm-ASH3 from Bm-ASH1 are two paral- lel and independent events, that is, further duplication of proneural genes occurs after or parallel to but not before the split of Diptera and Lepidoptera during evolution.

The medfly Ceratitis capitata, a member of family Tephritidae, has three AS-C homolog genes $C c-s c, C c-l$ 'sc and $C c$ ase. The bHLH domains of proteins coded by Ceratitis capitata acheate-scute homologs are highly conserved and display 95\%, 91.5\% and 90\% identity with the Drosophila counterparts, respectively [28]. Only one AS-C homolog, $B-A S H 1$, has been isolated from the Nymphalidae insect $P$. coenia [26]. B-ASH1 protein has a surprising identity with Bm-ASH2, 100\% within the bHLH domains and 


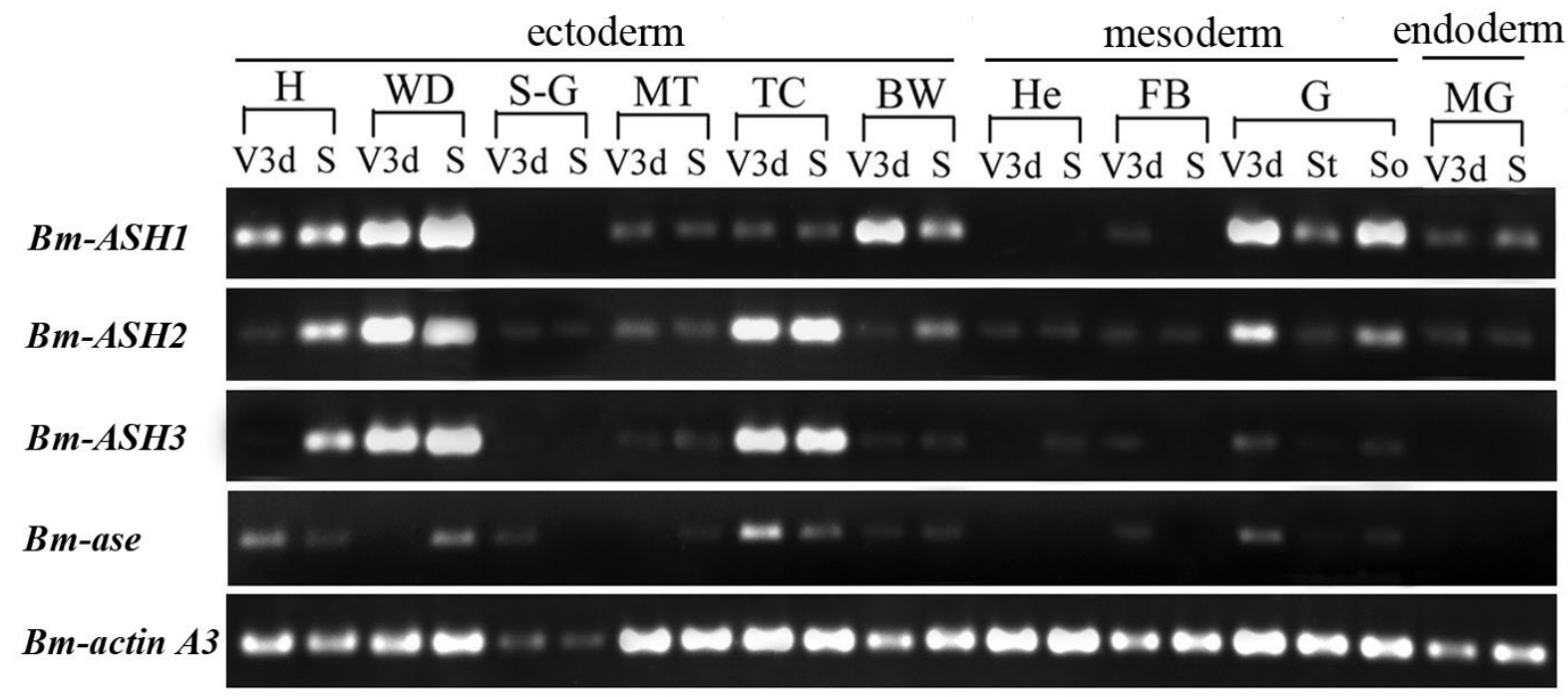

RT-PCR cycles

\section{Figure 6}

Tissue expression distribution of Bm-ASH genes in silkworm larvae. RT-PCR templates including: ectoderm tissues $\mathrm{H}$ (head), WD (wing disc), S-G (silk gland), MT (Malpighian tubule), TC (trachea cluster), BW (body wall); mesoderm tissues He (hemocyte), FB (fat body), G (gonad, T (testis), O (ovary)); and endoderm tissue MG (midgut). V3d stands for 3-day-old larvae of the 5th instar, and $\mathrm{S}$ stands for 8-day-old larvae of the 5 th instar (begin spinning). Amplification cycles were 30 for Bm-ASHI, $\mathrm{Bm}-\mathrm{ASH} 2, \mathrm{Bm}-\mathrm{ASH} 3$ and $\mathrm{Bm}$-ase, and 25 for the internal control gene Bm-actin A3.

$90.3 \%$ within the whole protein sequences. It is even higher than that between Bm-ASH2 and Bm-ASH3, 91.3\% within the bHLH domains and $49.8 \%$ within the whole protein sequences (Table 1). Moths first appeared on earth between 100 and 190 million years ago, and butter-

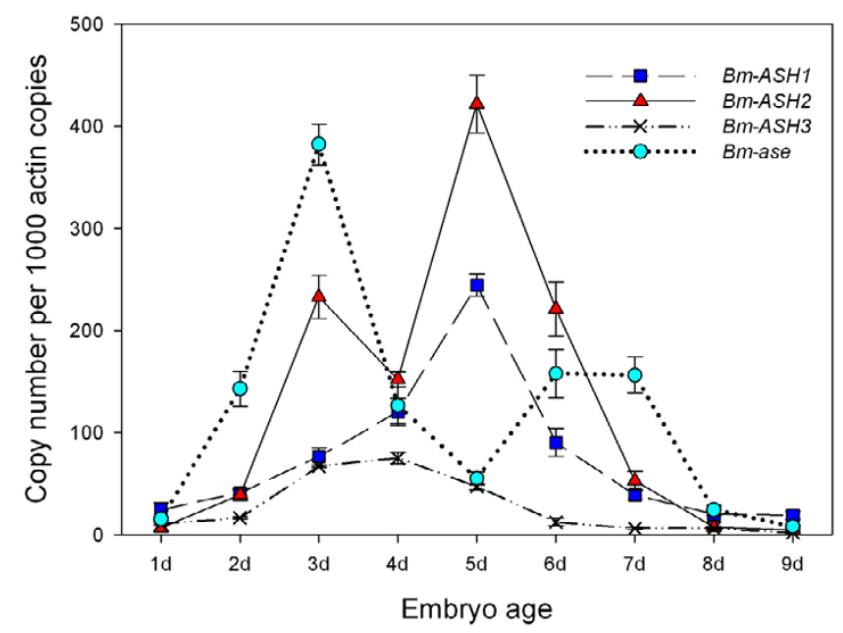

Figure 7

Developmental changes of $\mathrm{Bm}-\mathrm{ASH}$ genes in silkworm embryo. The numerical value are copy number of ASH cDNA per $10^{3}$ Bm-actin A3 cDNA copies. At least three independent repeats were carried out for each developmental stage. flies appeared about 40 million years ago, based on fossilized evidence. All above suggest that there are at least three AS-C genes in P. coenia, corresponding with $\mathrm{Bm}$ -

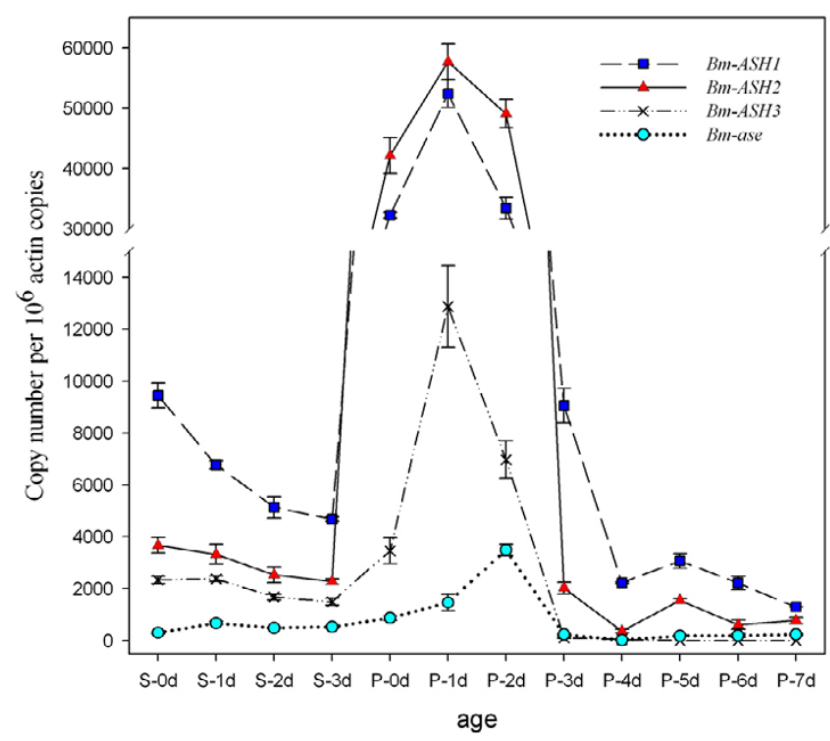

Figure 8

Developmental changes of Bm-ASH genes in silkworm wing disc/wing. The numerical value are copy number of ASH cDNA per $10^{6} \mathrm{Bm}$-actin A3 cDNA copies. S0$\mathrm{S} 3$ represent days after the beginning of spinning, and $\mathrm{P0}-\mathrm{P} 7$ represent days after pupation. At least three independent repeats were carried out for each developmental stage. 
Table 2: Homology comparison of proteins encoded by the Drosophila AS-C genes with some of the other insect ASH proteins.

\begin{tabular}{lccc}
\hline ASH name & \multicolumn{3}{c}{ Percent Identity (\%) } \\
\cline { 2 - 4 } & Dm-L'sc & Dm-Sc & Dm-Ac \\
\hline Dm-L'sc & $/$ & & \\
Dm-Sc & $73.5(34.6)$ & $/$ & \\
Dm-Ac & $69.1(35.8)$ & $66.7(33.8)$ & $/$ \\
Ag-ASH & $79.4(43.2)$ & $73.5(29.0)$ & $75.0(37.3)$ \\
Am-ASH & $72.1(26.6)$ & $69.6(28.9)$ & $66.7(33.3)$ \\
B-ASHI & $73.5(31.9)$ & $62.3(25.2)$ & $66.7(29.9)$ \\
Bm-ASHI & $74.6(40.9)$ & $68.7(42.0)$ & $68.7(31.6)$ \\
Bm-ASH2 & $72.1(31.0)$ & $62.3(27.2)$ & $65.7(28.9)$ \\
Bm-ASH3 & $72.1(34.9)$ & $58.0(27.4)$ & $65.2(30.3)$ \\
Tc-ASH & $70.6(34.2)$ & $65.2(33.2)$ & $63.9(33.8)$ \\
\hline
\end{tabular}

The number in the bracket is the identity percent between two whole protein sequences, and the number before the bracket is the identity percent within the bHLH regions.

ASH1, Bm-ASH2 and Bm-ase, respectively, and Bm-ASH3 might be the most recent one among the silkworm proneural genes.

\section{AS-C genes have a broad expression distribution in insect tissues}

$A S$ - $C$ genes are important for the development of the nervous system, and have key roles in regulating the formation and patterning of neural precursors. They are specially expressed in most of the proneural clusters during the development of either the central (CNS) or peripheral nervous system (PNS) in arthropod, such as flies, butterflies, beetles, bees, spiders, chilopods, etc. Other functions of these genes have also been found in Drosophila. l'sc participates in the specification of muscle progenitors [21], sc functions in sex determination [18] and ac regulates the development of Malphigian tubules [17].

In the present paper, we studied the expression of $B m-A S H$ genes in various silkworm larval tissues using RT-PCR methods. These genes are expressed in most organs derived from all three derms, showing they might have multiple functions during silkworm development. They have higher expression levels in the head, wing disc, tracheal cluster, body wall or gonad, and all of them are expressed in the organs though lower at some developmental points. This indicates that the genes might have overlapping functions, just as in Drosophila [42]. Expression profiles during the development of the embryo and the pupal wing also suggest co-operation characters of $\mathrm{Bm}$-ASH genes. During silkworm embryo development, neurogenesis takes place around 3 d-old, and trachea, bristle and appendage occur on $5 \mathrm{~d}$ and $6 \mathrm{~d}$. The correspondence between the two stages and those when the two expression peaks of $B m-A S H$ genes occure in the embryo (Fig. 7) suggests that these genes regulate the development of PNS and CNS. Expressions in wings of all the four genes are significantly higher on $1 \mathrm{~d}$ or $2 \mathrm{~d}$ after pupation than during other stages. Wing scale precursor cells form around the 2 d-old pupal stage [41], and our further studies on the scaleless wings mutant silkworm strongly proved the key role of $\mathrm{Bm}-\mathrm{ASH} 2$ in the formation of wing scales (Zhou et al., unpublished).

Although we have known many important functions of $A S-C$, the analysis of the structures and evolution of these genes may suggest some of their unknown functions. We compared the protein sequences of 38 AS-C homologs from vertebrate and invertebrate. There are conserved domains besides the bHLH and C-terminal motifs, especially within vertebrates. This conservation even exists between vertebrate and invertebrate organisms. A 20 amino acid conserved domain (corresponding to PEMRCKRRINFAQLGYNLPQ of Asp-ASH) was found in $A S H$ genes from vertebrates and myriapod animals Lithobius forficatus (Lf-ASH, Genbank: AAT99570) and Archispirostreptus (Asp-ASH, Genbank: AJ536345). Together with the broad expression of $B m$ - $A S H$ genes in tissues outside of the nervous system, they show that this gene family has other important functions waiting for exploration.

\section{Conclusion}

In this work, we isolate and identify four achaete-scute homologs from Bombyx mori. So far, Bombyx mori is the second insect which has been found to have four $A S-C$ genes. During organism evolution, genes are duplicated with conserved domains to gain more special functions. Results of phylogenetic and gene expression analysis show that during evolution, $A S-C$ genes duplication in insects occurs after or parallel to but not before the taxonomic order formation and functions of these genes are broad during insect development.

\section{Methods}

\section{Insects and cell culture}

The silkworm stock Jingsong $\times$ Haoyue was maintained in our laboratory. The insects were reared on an artificial diet at $25^{\circ} \mathrm{C}$ with $70 \%-80 \%$ relative humidity. Bm-N cells derived from silkworm were cultured at $27^{\circ} \mathrm{C}$ in TC- 100 insect medium containing $10 \%$ heat-inactivated $\left(56^{\circ} \mathrm{C}\right.$, $30 \mathrm{~min}$ ) fetal bovine serum (Invitrogen). Cell culture details were the same as Summers and Smith [43].

\section{RNA isolation and RT-PCR}

Silkworm tissues were dissected out at different stages and the total RNA was extracted with TRIZOL Reagent (Invitrogen) according to the standard protocol, and whole embryo total RNA was extracted using the acid-guanidine method [44]. One microgramme of total RNA from each sample was used to synthesize first-strand cDNA using M- 
MLV Reverse Transcriptase (Promega) as the protocol described. PCR with proper program was performed using the reverse transcription product as template. Sequences of all primers used in this paper are available upon request.

\section{Rapid amplification of CDNA ends (RACE)}

One microgramme of total RNA was used for RACE cDNA synthesis (BD SMART ${ }^{\mathrm{TM}}$ RACE cDNA Amplification Kit, Clontech), according to the user's manual. PCR was performed with primer1 and Universal Primer A Mix (UPM, Clontech), then a nest PCR was processed with primer2 and NUP using the suitable diluted former PCR product as the template. Each PCR reaction was carried out under the following conditions: one cycle of pre-denaturing for 5 min at $95^{\circ} \mathrm{C}$; and 30 cycles of $94^{\circ} \mathrm{C}$ for $40 \mathrm{~s}, 60^{\circ} \mathrm{C}$ for $40 \mathrm{~s}, 72^{\circ} \mathrm{C}$ for $3 \mathrm{~min}$, then followed by $10 \mathrm{~min}$ incubation at $72^{\circ} \mathrm{C}$.

\section{Database blast, protein sequences alignment and phylogenetic analysis}

We used the amino acid sequence coded by Drosophila achaete (Genbank: $\underline{\mathrm{AAF} 45498}$ ) to blast the silkworm EST database with the blastx program on the NCBI web site [45], by limiting the organism with "Bombyx mori". As formerly described [46], insect ASH protein sequences were aligned with CLUSTALX [47] and revised manually with Gendoc software. Then a neighbor-joining (NJ) tree based on amino acid sequences was constructed using the PHYLIP software package (100 bootstrap replicates) [48].

\section{Dual-Luciferase Reporter Assay}

Promoter segments were cloned into Luciferase Reporter Vector pGL3-Basic separately, and the ORF region of silkworm ASH and Drosophila da (GenBank: Y00221) genes were cloned into the modified $\mathrm{pBacPAK} 8$ vector with an IE1 promoter and a $h r 3$ enhancer [40]. Then the plasmids

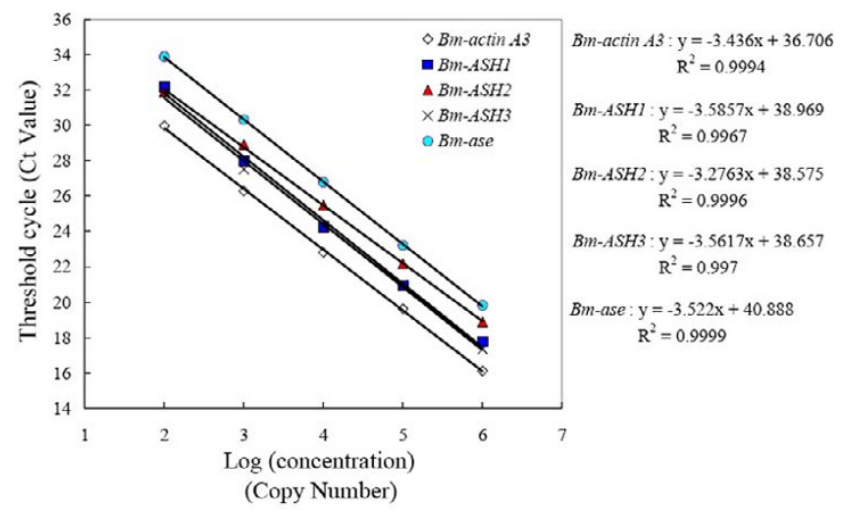

\section{Figure 10}

Standard curves of the Quantitative real-time PCR. Standard curves were constructed using serial dilutions of the ORF segments of the genes recombined into PMDI8-T vectors. The log ranges of the standard curves are from $10^{6}$ to $10^{2}$ copies. Threshold cycles of each standard dilution point were used to generate the standard curve for each gene. Linear equations corresponding to each standard curve are given, and $R^{2}$ for each standard curve is more than 0.99 .

were transfected into Bm-N cells as described formerly [49]. $0.1 \mu \mathrm{g}$ of pRL-CMV Vector was co-transfected as an internal control reporter for each transfection. After incubating for 48 hours, the cells were collected by centrifugation at $10,000 \mathrm{rpm}$ for $1 \mathrm{~min}$ at $4{ }^{\circ} \mathrm{C}$. Then the cell lysates were prepared using the passive lysis buffer, and $10 \mu \mathrm{g}$ of each lysate was used for the dual-luciferase reporter assay according to the protocol (Dual-Luciferase ${ }^{\circledast}$ Reporter $\left[D^{2} R^{\mathrm{TM}}\right]$ Assay System, Promega). Firefly luciferase activity and Renilla luciferase activity were determined with 20/ $20^{\text {n }}$ Luminometer (Turner BioSystems, Inc., USA). Each treatment was repeated at least three times.
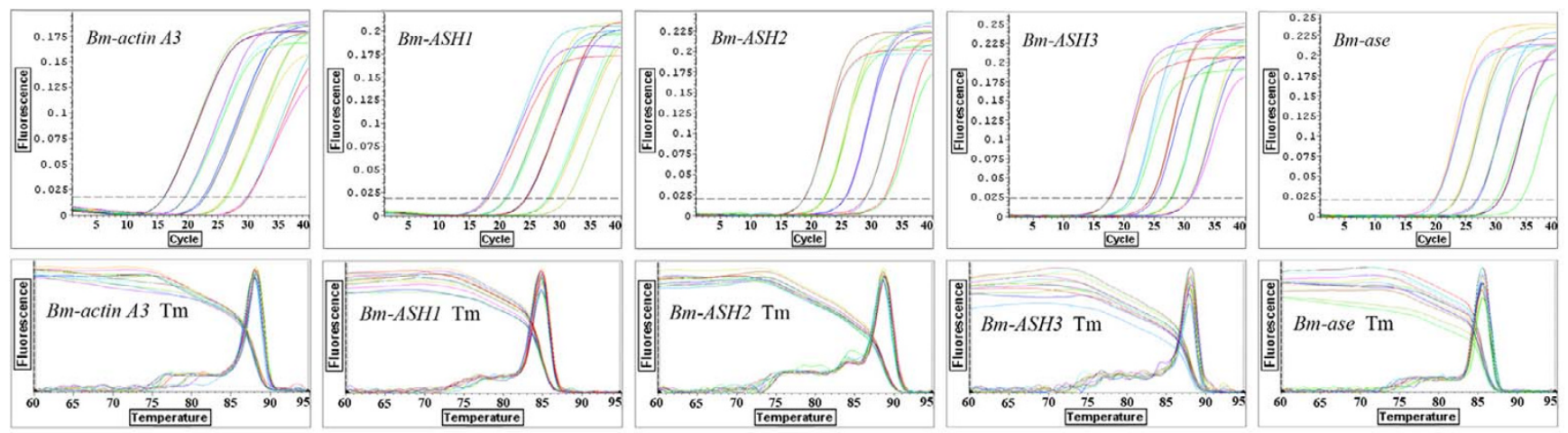

Figure 9

The data curves (upper) and melting curves (lower) of Quantitative real-time PCR for Bm-actin A3 and BmASH genes. These are the curves of amplifications for standard curve making. The plots show that the repeatability and specification of the Q-PCR are good. 


\section{Introduction of point mutation}

Primers P-F and P-R were designed at the terminals of the target segment sequence. Reversed primers $\mathrm{m}-\mathrm{R}$ and $\mathrm{m}-\mathrm{F}$ with the mutated bases were designed around the site where the point mutation would be introduced. PCRs were carried out with P-F pairing $\mathrm{m}-\mathrm{R}$ or $\mathrm{m}-\mathrm{F}$ paring $\mathrm{P}-\mathrm{R}$. After purification, the two PCR products were mixed, and denatured, renatured and extended for three cycles without any primers. Three cycles after running, P-F and P-R were added and the PCR was continued for 30 cycles of amplification. All of the PCRs were processed with $p f u$ DNA polymerase.

\section{Quantitative real-time PCR}

Q-PCR was used to determine the changes of silkworm ASH genes expression during embryo development and wing development. Primers were designed based on the cDNA sequence and a segment around 200 bp would be specially amplified for each gene. The housekeeping gene Bm-actin A3 was used as the internal control. A $20 \mu \mathrm{l}$ volume containing CDNA produced from about $10 \mathrm{ng}$ of total RNA, 5 pmol of each primer, and $10 \mu \mathrm{l}$ of SYBR Green Realtime PCR Master Mix (Toyobo Co., Ltd., Japan) was used for each PCR reaction. Then the PCR was processed on a Chromo4 Four-Color Real-Time System (Bio-Rad [formerly MJ Research]) under the following program: one cycle of $95^{\circ} \mathrm{C}$ for $3 \mathrm{~min}$; then 40 cycles of $95^{\circ} \mathrm{C}$ for 15 sec, $60^{\circ} \mathrm{C}$ for $15 \mathrm{sec}$ and $72^{\circ} \mathrm{C}$ for $30 \mathrm{sec}$. The melting curve was established from $60^{\circ} \mathrm{C}$ to $95^{\circ} \mathrm{C}$. Three independent repeats were carried out for each reaction. Threshold cycle values were used for the further analysis.

Standard curves were constructed using serial dilutions of the ORF segments of the genes recombined into pMD18$T$ vectors (Takara, Japan). The log ranges of the standard curves were from $10^{6}$ to $10^{2}$ copies. The data curve and the melting curve showed the reliability and specificity of the PCR product (Fig. 9). Threshold cycles of each standard dilution point were used to generate a reliable standard curve for each gene (Fig. 10). Linear equations corresponding to each standard curve were made, and $\mathrm{R}^{2}$ for each standard curve was more than 0.99. This showed that the linearity of the standard curves was good.

Theoretic copy of each sample was calculated with the linear equation for each gene, and trendlines for Bombyx ASH genes during the development course of silkworm embryo and pupal wing were constructed.

\section{Authors' contributions}

ZQX carried out most of the work and wrote the paper. ZTY isolated Bm-ASH1 and helped write the paper. YLL took part in RT-PCR and helped analyzing the data. YYZ cultured the cells. XWH and ZZF conceived the project and draft the manuscript. All authors read and approved the final manuscript.

\section{Acknowledgements}

The Drosophila daughterless cDNA used in the experiment was presented by Dr. Karen L. Schulze in Prof. Hugo J. Bellen's lab at Baylor College of Medicine. This work was supported by financial grants from the National High Technology Research and Development Program of China ("863" Project No. 2006AAI OAI 19) and the National Natural Sciences Foundation of China (30770279). We thank Ms. Zhenzhen Yang for the language editing of the manuscript.

\section{References}

I. Jan $Y N$, Jan $L Y$ : HLH proteins, fly neurogenesis, and vertebrate myogenesis. Cell 1993, 75:827-830.

2. Weintraub $H$ : The MyoD family and myogenesis: redundancy, networks, and thresholds. Cell 1993, 75: |24|-1244.

3. Hassan BA, Bellen HJ: Doing the MATH: is the mouse a good model for fly development? Genes Dev 2000, 14:1852-1865.

4. Massari ME, Murre C: Helix-loop-helix proteins: regulators of transcription in eucaryotic organisms. Mol Cell Biol 2000, 20:429-440.

5. Ledent $\mathrm{V}$, Paquet $\mathrm{Q}$, Vervoort M: Phylogenetic analysis of the human basic helix-loop-helix proteins. Genome Biol 2002, 3(6):research0030.003I.

6. Cubas P, de Celis J, Campuzano S, Modolell J: Proneural clusters of achaete-scute expression and the generation of sensory organs in the Drosophila imaginal wing disc. Genes Dev I99I, 5:996-1008.

7. Skeath J, Carroll SB: Regulation of achaete-scute gene expression and sensory organ pattern formation in the Drosophila wing. Genes Dev 1991, 5:984-995.

8. Jan YN, Jan LY: Genetic control of cell fate specification in Drosophila peripheral nervous system. Annu Rev Genet 1994, 28:373-393.

9. Calleja M, Renaud O, Usui K, Pistillo D, Morata G, Simpson P: How to pattern an epithelium: lessons from achaete-scute regulation on the notum of Drosophila. Gene 2002, 292:I-I2.

10. Cabrera CV, Alonso MC: Transcriptional activation by heterodimers of the achaete-scute and daughterless gene products of Drosophila. EMBO J 199I, 10:2965-2973.

II. Pi H, Huang SK, Tang CY, Sun H, Chien CT: phyllopod is a target gene of proneural proteins in Drosophila external sensory organ development. Proc Natl Acad Sci USA 2004, I01:8378-8383.

12. Van Doren M, Powell PA, Pasternak D, Singson A, Posakony JW: Spatial regulation of proneural gene activity: auto- and crossactivation of achaete is antagonized by extramacrochaetae. Genes Dev 1992, 6:2592-2605.

13. Campuzano S, Modolell J: Patterning of the Drosophila nervous system: the achaete-scute gene complex. Trends Genet 1992, 8:202-208.

14. Fichelson P, Gho M: The glial cell undergoes apoptosis inthe microchaete lineage of Drosophila. Development 2003, 130:123-133

15. Grens A, Mason E, Marsh JL, Bode HR: Evolutionary conservation of a cell fate specification gene: the Hydra achaete-scute homolog has proneural activity in Drosophila. Development 1995, I 2 I:4027-4035.

16. Wheeler SR, Carrico ML, Wilson BA, Brown SJ, Skeath JB: The expression and function of the achaete-scutegenes in Tribolium castaneum reveals conservation and variation in neural pattern formation and cell fate specification. Development 2003, 130:4373-438I.

17. Hoch M, Broadie K, Jackle H, Skaer H: Sequential fates in a single cell are established by the neurogenic cascade in the Malpighian tubules of Drosophila. Development 1994, I 20:3439-3450.

18. Parkhurst SM, Lipshitz HD, Ish-Horowicz D: achaete-scute feminizing activities and Drosophila sex determination. Development 1993, I I 7:737-749.

19. Deshpande G, Stukey J, Schedl P: scute (sis-b) function in Drosophila sex determination. Mol Cell Biol 1995, I5:4430-4440. 
20. Wrischnik LA, Timmer JR, Megna LA, Cline TW: Recruitment of the proneural gene scute to the Drosophila sex-determination pathway. Genetics 2003, 165:2007-2027.

21. Carmena A, Bate M, Jimenez F: lethal of scute, aproneural gene, participates in the specification of muscle progenitors during Drosophila embryogenesis. Genes Dev 1995, 9:2373-2383.

22. Alonso MC, Cabrera CV: The achaete-scute gene complex of Drosophila melanogaster comprises four homologous genes. $E M B O$ ] 1 988, 7:2585-2591.

23. Johnson JE, Birren SJ, Anderson DJ: Two rat homologues of Drosophila achaete-scute specifically expressed in neuronal precursors. Nature 1990, 346:858-86|.

24. Jasoni CL, Walker MB, Morris MD, Reh TA: A chicken achaetescute homolog (CASH-I) is expressed in a temporally and spatially discrete manner in the developing nervous system. Development 1994, 120:769-783.

25. Botella LM, Donoro C, Shchez L, Segarra C, Granadino B: Cloning and Characterization of the scute (sc) Gene of Drosophila subobscura. Genetics 1996, 144:1043-1051.

26. Galant R, Skeath JB, Paddock S, Lewis DL, Carroll SB: Expression pattern of a butterfly achaete-scute homolog reveals the homology of butterfly wing scales and insect sensory bristles. Curr Biol 1998, 8:807-8I3.

27. Persson P, Jogi A, Grynfeld A, Pahlman S, Axelson H: HASH-I and E2-2 Are Expressed in Human Neuroblastoma Cells and Form a Functional Complex. Biochem Biophys Res Commun 2000 274:22-31.

28. Wülbeck C, Simpson P: Expression of achaete-scute homologues in discrete proneural clusters on the developing notum of the medfly Ceratitis capitata, suggests a common origin for the stereotyped bristle patterns of higher Diptera. Development 2000, I 27: | 4 I |-1420.

29. Pistillo D, Skaer N, Simpson P: scute expressionin Calliphora vicina reveals an ancestral pattern of longitudinal stripes on the thorax of higher Diptera. Development 2002, I 29:563-572.

30. Skaer N, Pistillo D, Gibert JM, Lio P, Wülbeck C, Simpson P: Gene duplication at the achaete-scute complex and morphological complexity of the peripheral nervous system in Diptera. Trends in Genetics 2002, 18:399-405.

31. Wülbeck C, Simpson P: The expression of pannier and achaetescute homologues in a mosquito suggests an ancient role of pannier as a selector gene in the regulation of the dorsal body pattern. Development 2002, I 29:386 I-387I.

32. Jonsson M, Mark EB, Brantsing C, Brandner JM, Lindahl A, Asp J: Hash4, a novel human achaete-scute homologue found in fetal skin. Genomics 2004, 84:859-866.

33. Seipel K, Yanze N, Schmid V: Developmental and evolutionary aspects of the basic helix-loop-helix transcription factors Atonal -like I and Achaete-scute homolog 2 in the jellyfish. Dev Biol 2004, 269:33 I-345.

34. Schlatter R, Maier D: The Enhancerof split and Achaete-Scute complexes of Drosophilids derived from simple ur-complexes preserved in mosquito and honeybee. BMC Evol Biol 2005, 5:67.

35. Xia Q, Zhou Z, Lu C, Cheng D, Dai F, Li B, Zhao P, Zha X, Cheng T, Chai C, Pan G, Xu J, Liu C, Lin Y, Oian J, Hou Y, Wu Z, Li G, Pan M, Li C, Shen Y, Lan X, Yuan L, Li T, Xu H, Yang G, Wan Y, Zhu Y, Yu $M$, Shen W, Wu D, Xiang Z, Yu J, Wang J, Li R, Shi J, Li H, Li G, Su J Wang X, Li G, Zhang Z, Wu Q, Li J, Zhang Q, Wei N, Xu J, Sun H, Dong L, Liu D, Zhao S, Zhao X, Meng Q, Lan F, Huang X, Li Y, Fang L, Li C, Li D, Sun Y, Zhang Z, Yang Z, Huang Y, Xi Y, Qi Q, He D, Huang H, Zhang X, Wang Z, Li W, Cao Y, Yu Y, Yu H, Li J, Ye J, Chen H, Zhou Y, Liu B, Wang J, Ye J, Ji H, Li S, Ni P, Zhang J, Zhang Y, Zheng $\mathrm{H}$, Mao B, Wang W, Ye C, Li S, Wang J, Wong GK, Yang H, Biology Analysis Group: A draft sequence for the genome of the domesticated silkworm (Bombyx mori). Science 2004, 306(5703): 1937-1940.

36. Rogers $S$, Wells R, Rechsteiner M: Amino acid sequences common to rapidly degraded proteins: the PEST hypothesis. Science 1986, 234:364-368.

37. González F, Romani S, Cubas P, Modolell J, Campuzano S: Molecular analysis of the asense gene, a member of the achaete-scute complex of Drosophila melanogaster, and its novel role in optic lobe development. EMBO J 1989, 8:3553-3562.

38. Hinz U, Giebel B, Campos-Ortega JA: The basic-helix-loop-helix domain of Drosophila lethal of scute protein is sufficient for proneural function and activates neurogenic genes. Cell 1994 , 76:77-87.

39. Wang J, Xia Q, He X, Dai M, Ruan J, Chen J, Yu G, Yuan H, Hu Y, Li $\mathrm{R}$, Feng T, Ye C, Lu C, Wang J, Li S, Wong GK, Yang H, Wang J, Xiang Z, Zhou Z, Yu J: SilkDB: a knowledgebase for silkworm biology and genomics. Nucleic Acids Research 2005, 33:D399-D402.

40. Chen Y, Yao B, Zhu Z, Yi Y, Lin X, Zhang Z, Shen G: A constitutive super-enhancer: homologous region 3 of Bombyx mori nucleopolyhedrovirus. Biochem Biophys Res Commun 2004, 31 8: 1039-1044.

4l. Zhou Q, Li Y, Shen X, Yi Y, Zhang Y, Zhang Z: The scaleless wings mutant in Bombyx mori is associated with a lack of scale precursor cell differentiation followed by excessive apoptosis. Dev Genes Evol 2006, 2 16:721-726.

42. Marcellini S, Gibert JM, Simpson P: achaete, but not scute, is dispensable for the peripheral nervous system of Drosophila. Dev Biol 2005, 285:545-553.

43. Summers M, Smith G: A Manual of Methods for Baculovirus Vectors and Insect Cell Culture Procedures. Texas Agricultural Experiment Station bulletin 1987, I555:

44. Chomczynski P, Sacchi N: Single-step method of RNA isolation by acid guanidinium thiocyanate-phenol-chloroform extraction. Anal Biochem 1987, 162:156-159.

45. NCBI/BLAST/blastx [http://www.ncbi.nlm.nih.gov/ blasast.cgi?PAGE $=$ Translations\&PRO GRAM=blast $x \& B L A S T$ PROGRAMS=blast $x \& P A G E$ TYPE=BlastS earch\&SHOW DEFAULTS=on]

46. Xia A, Zhou Q, Yu L, Li W, Yi Y, Zhang Y, Zhang Z: Identification and analysis of YELLOW protein family genes in the silkworm, Bombyx mori. BMC Genomics 2006, 7:195.

47. Jeanmougin F, Thompson JD, Gouy M, Higgins DG, Gibson TJ: Multiple sequence alignment with ClustalX. Trends Biochem Sci 1998, 23:403-405

48. Felsenstein J: PHYLIP: Phylogentic inference package. In version 3.6 Washington: Department of Genome Sciences, University of Washington; 2002.

49. Zhou Y, Xiao O, Zhang Z, He J, Zhang Y: Foreign insect hormones stimulating the transcription of the ie-l promoter of Bombyx mori nuclear polyhedrosis virus in vivo and in vitro. Biosci Biotechnol Biochem 2002, 66: | 488-1494.
Publish with Bio Med Central and every scientist can read your work free of charge

"BioMed Central will be the most significant development for disseminating the results of biomedical research in our lifetime. "

Sir Paul Nurse, Cancer Research UK

Your research papers will be:

- available free of charge to the entire biomedical community

- peer reviewed and published immediately upon acceptance

- cited in PubMed and archived on PubMed Central

- yours - you keep the copyright
BiolMedcentral 